\title{
Akademicka Księgarnia Spółdzielcza „Skrypt” w Toruniu w latach 1945-1950
}

$\bigwedge \begin{aligned} & \text { kademicka Księgarnia Spółdzielcza „Skrypt” działała na terenie } \\ & \text { Uniwersytetu M. Kopernika w Toruniu jako autonomiczna age- } \\ & \text { nda Bratniej Pomocy, organizacji młodzieżowej mającej na celu }\end{aligned}$ wspieranie finansowo niezamożnych studentów. Produkcja tanich podręczników, jaką prowadził Skrypt, była jedną z form takiego wsparcia, szczególnie ważną w okresie gdy każda polska książka była trudno osiągalna. Spółdzielnia powstała dzięki zainteresowaniu i zaangażowaniu studentów. Wyraźny wpływ na jej istnienie, szczególnie w ostatnim etapie działania, wywarła zaostrzająca się sytuacja polityczna i dążenie do upaństwowienia wszystkich przedsiębiorstw i firm wydawniczych. Chociaż ostateczną decyzję o rozwiązaniu Skryptu powzięto pod koniec 1949 roku, działalność wydawniczą zawieszono dopiero w lutym 1950, a sam proces likwidacji przeciagnął się aż do maja 1952 roku. Dlatego za faktyczny koniec istnienia Spółdzielni należy uznać rok 1950.

\section{Stan badań. Źródła}

Dotychczas działalność Skryptu doczekała się tylko kilku marginalnych wzmianek w artykułach omawiających historię organizacji studenckich działających w Toruniu w pierwszych latach istnienia uniwersytetu' 1 . Problematyką tą zajmował się przede wszystkim Henryk Galus w swoich pracach poświęconych ruchowi młodzieżowemu². Powstały one przed kilkunastu laty, co wyrażnie zaważyło na sposobie ujęcia tematu, a tym samym pośrednio wpłynęło na niniejszy artykuł. Niestety brak współczesnych opracowań poruszających to zagadnienie.

Warto zaznaczyć, że zachował się bogaty materiał źródłowy, dotychczas nie wykorzystany, dokumentujący działalność Skryptu w postaci bilansów, umów o pracę, sprawozdań, a przede wszystkim protokołów walnych zgromadzeń Spółdzielni. Całość jest przechowywana w Archiwum Państwowym (AP) w Toruniu w odrębnym zespole pod nazwą AkademicZ Badań Nad Polskimi Ksiegozbioram Historycznymi t. 21, Warszawa 2003. 
ka Księgarnia Spółdzielcza Skrypt. Większość z tych dokumentów jest także zawarta w aktach jednostki nadrzędnej dla Skryptu, Centrali Spółdzielni Wydawniczych i Księgarskich (CSWiK), znajdujących się w Archiwum Akt Nowych w Warszawie. Dodatkowo przechowywane sq̨ tam dokumenty zawierające decyzje CSWiK dotyczące likwidacji Akademickiej Księgarni Spółdzielczej Skrypt.

Materiały te uzupełnione o informacje zaczerpnięte z akt Związku Rewizyjnego Spółdzielni RP (również przechowywane w AP Toruń) oraz o dane dotyczące organizacji studenckich, pochodzące z Archiwum UMK, stały się podstawą niniejszego artykułu. Istotnych wiadomości dostarczyły także sprawozdania z działalności Skryptu zamieszczane na łamach miesięcznika akademickiego Alma Mater Thorunensis oraz krótkie notatki na temat tej Spóldzielni ukazujące się w Robotniku Pomorskim w ramach stałej rubryki Kronika toruńska.

Próby ustalenia produkcji wydawniczej Skryptu nie w pełni odniosły skutek, niemniej przeanalizowanie odnalezionych wydawnictw pozwoliło na wyciagnięcie wniosków wzbogacających obraz tej Spółdzielni.

Znaczny wpływ na ostateczny kształt artykułu miała korespondencja z osobami zaangażowanymi w działalność Skryptu ${ }^{3}$. Szczególnie cenne okazały się informacje prof. Adeli Styczyńskiej, ówczesnej studentki Uniwersytetu M. Kopernika i maszynistki w Spółdzielni.

\section{Organizacje studenckie}

Akademicka Księgarnia Spółdzielcza Skrypt funkcjonowała w latach 1945-50, a więc w okresie powstania i rozwoju toruńskiego uniwersytetu. Wówczas to na nowo tworzoną uczelnię zgłaszała się młodzież o zróżnicowanym pochodzeniu społecznym i odmiennych poglądach politycznych ${ }^{4}$. Ta konfrontacja postaw znajdowała wyraz w działalności większej liczby organizacji studenckich o różnorodnym profilu społeczno-politycznym. Warto zaznaczyć, że zróżnicowanie toruńskiego ruchu studenckiego odzwierciedlało sytuację jako panowała na wszystkich uniwersytetach w pierwszych latach „demokracji ludowej”. Spośród organizacji politycznych należy tu wymienić Akademicki Związek Walki Młodych „Życie”, Związek Niezależnej Młodzieży Socjalistycznej, Związek Młodzieży Akademickiej „Jedność”, który istniał przez krotki okres czasu oraz Związek Młodzieży Wiejskiej „Wici” i Związek Młodzieży Demokratycznej. Organizacje te powstały na toruńskiej uczelni jesienią 1945 roku i od początku zajmowały dominującą pozycję na arenie politycznej środowiska studenckiego. 
Oprócz organizacji politycznych na Uniwersytecie M. Kopernika funkcjonowały stowarzyszenia katolickie jak Caritas Academica, Juventus Christiana czy Sodalicja, których powołanie było próbą powrotu do przedwojennych tradycji środowiska studenckiego. Wyrazem tej tendencji było także powstanie na jesieni 1945 roku Związku Studentów UMK Bratnia Pomoc 5 . Była to organizacja samopomocowa, samorządowa o charakterze bezpartyjnym. Wyboru pierwszego zarządu dokonano 28 października $1945 \mathrm{r}$. na specjalnym posiedzeniu komisji porozumiewawczej organizacji akademickich'. W jego skład weszli przedstawiciele AZWM „Życie”, ZMD oraz Organizacji Młodzieży TUR ${ }^{7}$. Pierwszym prezesem Bratniej Pomocy został Jerzy Zaremba reprezentujący AZWM „Życie”. Na kuratora wyznaczono, pismem z dnia 4 maja 1946, prof. Tadeusza Czeżowskiego ${ }^{8}$.

Bratnia Pomoc jako organizacja apolityczna nie stawiała sobie żadnych zadań i celów wychowawczych'. Jej podstawowym założeniem programowym była troska o sprawy socjalno-bytowe studentów oraz udzielanie im pomocy materialnej poprzez prowadzenie własnej działalności gospodarczej. Toruńska Bratnia Pomoc koncentrowała się na zapewnieniu młodzieży przybywającej do miasta wyżywienia i właściwych warunków mieszkaniowych. Służyło temu zorganizowanie stołówki akademickiej i domów studenckich. Środki na te przedsięwzięcia czerpano z mająıku Kuczwały, który otrzymano w kwietniu 1946 roku oraz z studenckich zakładów usługowych ${ }^{10}$.

Bratnia Pomoc troszczyła się także o akademickie życie kulturalne. W styczniu $1946 \mathrm{z}$ okazji inauguracji roku akademickiego wydano 25 stronicową Jednodniówkę, a następnie 5 numerów czasopisma społeczno-kulturalnego pod tytułem Alma Mater Thorunensis ${ }^{11}$.

Wszelkie działania toruńskiej Bratniej Pomocy miały na celu wspieranie studentów w pierwszym, trudnym okresie organizowania i zagospodarowywania Uniwersytetu M. Kopernika.

Warto w tym momencie przypomnieć powieść Zdzisława Wróbla Inauguracja (Warszawa 1954), w której autor w zakamuflowany, ale jednocześnie łatwy do rozszyfrowania sposób opisuje toruński uniwersytet jako miejsce ostrej walki politycznej. Należy tu dodać, iż autor występuje oczywiście jako zwolennik partii i nowego ustroju. Pomimo tego, utwór ten nie cieszył się zbyt dobrymi recenzjami. Zarzucano mu min. schematyzm i znaczne uproszczenia ${ }^{12}$, niemniej wzbudził spore zainteresowanie. Podstawą dyskusji był fakt, iż Z. Wróbel nazbyt wiernie opisał znane sobie osoby przedstawiając je nie zawsze w korzystnym świetle. 
Wraz z upływem czasu i umocnienia się władzy ludowej zaczęto dążyć do ujednolicenia ruchu studenckiego. Decyzje o tym fakcie zapadały na szczeblu centralnym. Pierwszym krokiem było utworzenie, w lutym 1948 roku, na zjeździe w Krakowie ogólnopolskiej organizacji studenckiej - Federacji Polskich Organizacji Studenckich (FPOS) ${ }^{\prime 3}$. Federacja skupiła działaczy AZWM „Życie”, Związku Niezależnej Młodzieży Socjalistycznej, ZMW „Wici”, ZMD oraz 55 na 60 istniejących Bratnich Pomocy, 19 na 250 istniejących Kół Naukowych i Akademickie Związki Sportowe. Całkowity kres różnorodności ruchu studenckiego, nastapił na Kongresie Studentów Polskich, który odbył się 17 - 18 kwietnia 1950 roku w Warszawie ${ }^{14}$. Kongres postanowił przekształcić FPOS w ,jednolitą powszechną $i$ dobrowolną organizację o funkcjach zawodowych" - Zrzeszenie Studentów Polskich (ZSP). Jednocześnie ZSP przejęło cały majątek i działalność FPOS. Kongres polecił także zaprzestania działalności Bratnich Pomocy, a ich majątek przekazał nowo powstałemu ZSP. Zgodnie z zarządzeniami Kongresu toruński Konitet Środowiskowy FPOS przekształcił się w maju 1950 w Komitet Uczelniany ZSP, a Bratnia Pomoc Studentów UMK uległa likwidacji ${ }^{15}$.

\section{Skrypt - Zgromadzenie Założycielskie}

Akademicka Księgarnia Spółdzielcza Skrypt działała jako autonomiczna agenda Bratniej Pomocy, organizacji młodzieżowej mającej na celu wspieranie finansowo niezamożnych studentów. Produkcja tanich podręczników była jedną z form takiego wsparcia, szczególnie ważną w okresie, gdy polski rynek wydawniczy dopiero odbudowywał się ze zniszczeń wojennych. Skrypt powołano do życia na Zgromadzeniu Założycielskim spółdzielni zwołanym 19 listopada 1945 roku $^{16}$. Odbyło się ono w lokalu Bratniej Pomocy (Dom Akademicki, ul. Mickiewicza 2/4) o godz. 175. Na zebranie przybyło aż 50 osób ${ }^{17}$, co świadczy o dużym zainteresowaniu jeszcze przed zawiązaniem Spółdzielni. Zgromadzenie zagaiła Barbara Zdrójkowska ${ }^{18}$, studentka Wydziału Prawa. Na przewodniczącego Zgromadzenia Założycielskiego powołano Adama Felskiego, studenta Wydziału Prawno-Ekonomicznego, na asesorów Jerzego Zarembę - prezesa Bratniej Pomocy oraz Henryka Jarzęckiego. Funkcje sekretarza objął Marian Kryszewski, przyszły asystent przy Katedrze Chemii Nieorganicznej ${ }^{19}$. Następnie mgr Zbigniew Zdrójkowski ${ }^{20}$ odczytał i wyjaśnił Statut Spółdzielni, który po wniesieniu kilku uzupełnień, przyjęto i podpisano. Zgodnie z postanowieniami Statutu wybrano Radę Nadzorczą w skład której weszli: mgr Tadeusz Cieślak, Wacław Zarzycki, Czesław Żyła, Konrad Gęsicki, Jerzy Zaremba, Marian Dziarnowski, Janusz Rajchman, Henryk Jarzęcki, Danuta Staniszewska, 
Jan Domański ${ }^{21}$. Tuż po zakończeniu obrad zgromadzenia i półgodzinnej przerwie Rada Nadzorcza zebrała się o godz. $19^{00}$ w celu omówienia spraw związanych z działalnością Spółdzielni ${ }^{22}$. Dokonano wyboru przewodniczącego Rady, którym został mgr Tadeusz Cieślak ${ }^{23}$, a przede wszystkim wyboru członków Zarządu i podziału obowiązków pomiędzy nimi. Ostatecznie skład pierwszego Zarządu przedstawiał się następująco: przewodniczący - Barbara Zdrójkowska, zastępca przewodniczącego - Adam Felski, sekretarz - Marian Kryszewski, skarbnik - Alicja Żukowska, członek Zarządu - Władysław Chodkiewicz. Rada Nadzorcza upoważniła Zarząd do zaangażowania potrzebnej ilości pracowników, nabycia ruchomości oraz pomocy naukowych potrzebnych członkom. Zarząd zobowiązano ponadto do prowadzenia propagandy mającej na celu pozyskania nowych członków, a dzięki temu powiększenie funduszu udziałowego.

Jeszcze tego samego dnia Zarząd zwrócił się, zgodnie z wymaganiami ustawy o spółdzielniach z dnia 29 października 1920 roku, do Wydziału Rejestru Handlowego Sądu Okręgowego w Toruniu o zarejestrowanie statutu i o wciagnięcie do rejestru nazwisk członków Zarządu ${ }^{24}$. Zarząd Skryptu, posługując się nazwą „Akademicka Spółdzielnia Wydawnicza Skrypt Bratniej Pomocy Uniwersytetu im. M. Kopernika", podpisał także Deklarację przystapienia do Związku Rewizyjnego Spółdzielni R.P. ${ }^{25}$, poddając się jego nadzorowi i opiece oraz zobowiązując się do stosowania w swojej działalności wszelkich uchwał i wskazówek wydawanych przez Związek.

Związek Rewizyjny Spółdzielni Rzeczpospolitej Polskiej ${ }^{26}$ to jedna $\mathrm{z}$ dwóch central koordynujących ruch spółdzielczy. Na podstawie orzeczeń o celowości wydawanych przez tą organizację mogły powstawać spółdzielnie. Związek Rewizyjny był także zobowiązany do czuwania, poprzez swoich rewidentów, nad zgodnością całego aparatu spółdzielczego z prawem i zasadami spółdzielczymi.

Związek Rewizyjny Okręg Pomorski 14 grudnia 1945 roku przedłożył Centrali w Lodzi akta rejestracyjne Skryptu z prośbą o wyrażenie zgody na jego powstanie ${ }^{27}$. Jednocześnie wyjaśniono, iż czyniono starania oparcia Spółdzielni na statucie spółdzielni uczniowskiej, ale rektor Uniwersytetu M. Kopernika nie wyraził zgody na przyjęcie funkcji patronackiej ${ }^{28}$. W odpowiedzi Centrala zasugerowała założenie akademickiej księgarni spółdzielczej jako formy bardziej odpowiadającej planowanym zamierzeniom gospodarczym, w przeciwieństwie do spółdzielni wydawniczej przed którą stawiano szersze zadania. Dodatkowo zastrzeżono, iż teren działalności Spółdzielni musi się ograniczać wyłącznie do uczelni bez moźliwości założenia skle- 
pu „na mieście” i tylko w takim wypadku zostanie wydane oświadczenie o celowości założenia Akademickiej Księgarni Spółdzielczej Skrypt. Ostatecznie Związek Rewizyjny wystawił je 20 grudnia 1945 roku $^{29}$.

\section{Statut AKS Skrypt}

Końcowym efektem powyższych konsultacji są dwa statuty: Statut Akademickiej Spółdzielni Wydawniczej Skrypt Studentów Bratniej Pomocy Uniwersytetu im. M. Kopernika w Toruniu oraz Statut Akademickiej Księgarni Spółdzielczej z odpowiedzialnością udziałami w Toruniu przechowywane w AP w Toruniu, z których tylko statut księgarni podpisany jest przez założycieli.

Akademicką Księgarnię Spółdzielczą Skrypt z odpowiedzialnością udziałami zawiązano na mocy ustawy o spółdzielniach z dnia 29 października 1920 roku ${ }^{30}$. Powołano ją w celu, ,wydawania skryptów na podstawie wykladów uniwersyteckich oraz ulatwiania studentom nabywania wszelkich pomocy naukowych" (\$1). Swoje zadania Spółdzielnia zamierzała realizować poprzez organizowanie notowania wykładów na poszczególnych wydziałach, wydawanie skryptów, pośredniczenie w nabywaniu przez studentów pomocy naukowych (§3). Za siedzibę Spółdzielni uznano Dom Akademicki w Toruniu, natomiast za teren działalności - Uniwersytet M. Kopernika ( 55 ).

Zgodnie z postanowieniami Statutu członkami Spółdzielni mogli zostać studenci, osoby związane $z$ uniwersytetem (profesorowie, asystenci, itp.) oraz inne osoby, na których przyjęcie Zarząd wyraził zgodę ( $\$ 6$ ). Warunkiem zaliczenia w poczet członków było uiszczenia wpisowego w wysokości $10 \mathrm{zł}$ oraz wykupienia udziału o wartości $100 \mathrm{zł}$, z czego $25 \mathrm{zł}$ stanowiło obowiązkową część udziału płatną gotówką przy zapisaniu do Spółdzielni, a pozostała kwota miała być wpłacona w trzech ratach po $25 \mathrm{zł} \mathrm{miesięcz-}$ nie $(\S 11)$.

Najwyższe władze Spółdzielni stanowiło walne zgromadzenie do którego kompetencji należał m. in. wybór i odwołanie rady nadzorczej, zatwierdzanie bilansów i sprawozdań rocznych, postanowienia o zmianie statutu i rozwiązanie Spółdzielni (§19). Rada nadzorcza składała się z 10 członków wybieranych na przeciagg jednego roku przez walne zgromadzenie. Zarząd Bratniej Pomocy przedstawiał listę ośmiu kandydatów, spośród których walne zgromadzenie wybierało sześciu. Pozostałych 4 członków rady nadzorczej wybierało walne zgromadzenie spośród kandydatów wyłonionych przez siebie ( $\$ 23)$. Organem kierowniczym i wykonawczym Spółdzielni był zarząd, składający się z 5 osób powoływanych przez radę nadzorczą spośród członków Spółdzielni na okres jednego roku (§28). Do zadań zarządu nalało 
min. bezpośrednie zarządzanie sprawami gospodarczymi, administracyjnymi i organizacyjnymi Spółdzielni oraz przyjmowanie i zwalnianie pracowników i zawieranie z nimi umów ( $(29)$.

O likwidacji Spółdzielni decydowało walne zgromadzenie większością 3/4 głosów oddanych na dwóch kolejnych zebraniach w odstępie co najmniej dwóch tygodni. Likwidatorami ustanawiano członków ostatniego zarządu, o ile walne zgromadzenie nie wybrało innych osób (§38).

Statut podpisali członkowie założyciele studenci Wydziału Prawa: Barbara Zdrójkowska, Janusz Rajchman, Marian Dziarnowski, Henryk Jarzęcki, Czesław Żyła, Janina Dziarnowska, Stanisław Bieńkowski, Renata Antoniewicz; Wydziału Matematyczno-Przyrodniczego: Marian Kryszewski, Alicja Żukowska, Danuta Staniszewska, Władysław Chodkiewicz oraz Tadeusz Cieślak urzędnik „Samopomocy Chłopskiej”, Tadeusz Perdyński major Wojska Polskiego, Janina Bednowska - stenotypistka.

Pewne korekty do Statutu wprowadzono na Walnym Zgromadzeniu w dniu 17 marca $1948^{31}$. Zmieniono wówczas treść $§ 5,23$ i 28 oraz wzbogacono o $\$ 25$. Zgodnie $\mathrm{z}$ wprowadzonymi modyfikacjami rozszerzono teren działalność Spółdzielni na miasto Toruń, zmniejszono skład rady nadzorczej z 10 do 6 członków i 2 zastępców wybieranych na przeciąg 3 lat oraz ograniczono do 3 osób liczebność zarządu. Nowo dodany $\$ 25$ dotyczył wymiany co roku $1 / 3$ członków i zastępców wchodzących w skład rady nadzorczej. Przypuszczalnie zmiany te były wynikiem stopniowego spadku liczby członków Spółdzielni i ich aktywności po rozpoczęciu przez Koło Prawników samodzielnej działalności wydawniczej.

\section{Zmiany w składzie osobowym spóldzieIni. Sprawy organizacyjne}

W 1945 roku Spółdzielnia była jeszcze na etapie organizowania się i nie prowadziła żadnej działalności gospodarczej. Wydatki związane z zakupem potrzebnych materiałów i sprzętu pokrywano z udziałów członkowskich. Rosła liczba członków Spółdzielni i pod koniec pierwszego roku istnienia Skryptu wynosiła już 182 osoby ${ }^{32}$. Stale przyjmowano nowe zgłoszenia i deklaracje, tak że pod koniec stycznia 1946 roku Spółdzielnia posiadała

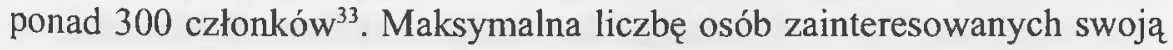
działalnością Skrypt wykazał w sprawozdaniu za rok $1948^{34}$. Był to efekt celowych działań polegających na „wygłaszaniu sloganów propagandowych w programach radiowych „Bratniej Pomocy Studentów UMK” oraz wywieszaniu plakatów propagandowych"35. Spółdzielnia liczyła wówczas 402 członków, w tym 4 organizacje ideowo-wychowawcze. Na pozostałych 398 członków fizycznych składało się m.in. 2 naukowców, 4 dziennikarzy 
i publicystów, 38 nauczycieli, 3 pracowników kulturalno-oświatowych oraz I pracownik branży księgarskiej.

O swoich dokonaniach Spółdzielnia informowała studentów w comiesięcznych sprawozdaniach ukazujących się na łamach czasopisma akademickiego Alma Mater Thorunensi s $^{36}$. Zamieszczano tam informacje o wydanych i przygotowywanych skryptach, staraniach Zarządu o przydziały papieru, liczebności pracowników w dziale technicznym. Ponadto wykorzystywano ten organ prasowy do przypomnienia członkom Spółdzielni o uiszczeniu zaległych rat udziałów.

Pomimo dużego zainteresowania działalnością Księgarni Spółdzielczej kilkakrotnie powracała sprawa jej dalszego istnienia. 17 września 1946 roku odbyło się Walne Zgromadzenie członków Skryptu, na którym poza przyjęciem sprawozdania $\mathrm{z}$ dotychczasowej działalności Zarządu dyskutowano nad przyszłością Spółdzielni ${ }^{37}$. Kwestię tą podjęto w odpowiedzi na pismo Koła Prawników Studentów $\mathrm{UMK}^{38}$. W nadesłanej nocie domagali się oni rozwiązania Spółdzielni i przekazania jej majątku na rzecz Koła w celu dalszego kontynuowania wydawania skryptów prawniczych. Ponieważ dokument ten nie zachował się, można tylko przypuszczać jaka była argumentacja prawników. Ta grupa studentów dominowała wśród członków spółdzielni. Była najliczniejsza, a zarazem najaktywniejsza, przygotowała największą ilość skryptów. Ukazywały się one w najwyższym nakładzie, a tym samym przynosiły dochód. Przeznaczano go na dofinansowanie skryptów $\mathrm{z}$ innych wydziałów, co mogło wywołać niezadowolenie prawników.

$\mathrm{Na} z e b r a n i u$ Spółdzielni poświęconym temu zagadnieniu przewodniczący Koła, Zbigniew Jaśkiewicz ${ }^{39}$, zobowiązał się w imieniu prawników do wydawania skryptów pozostałych wydziałów, zaznaczając że odpowiedzialność za ich treść oraz przygotowanie ponosić będą odpowiednie koła naukowe. W toku dyskusji jaka się zawiązała nad złożona propozycją, podjęto problem wielkości pozostałych kół naukowych, które jako mniej liczne niż Koło Prawników nie byłyby w stanie podjać się samodzielnej działalności wydawniczej, a tym samym pozostawałyby w pewnej zależności od prawników. Wyrażano również obawy czy Koło Prawników dotrzyma swoich zobowiązań.

Sytuacje dodatkowo skomplikowało ustappienie dotychczasowego Zarządu Spółdzielni. Jako przyczynę rezygnacji przewodnicząca Zarządu, Barbara Zdrójkowska, podała „trudności technicznej natury” tzn. obowiązek prowadzenia propagandy spółdzielczość oraz prac społeczno-kulturalnych wymaganych przez Związek Rewizyjny Spółdzielni R. P. Zaliczało się 
do nich organizowanie klubów książki, uruchomienie w powiecie własnych punktów sprzedaży, branie udziahu w akcji „książka na wieś”. Swoją działalność w tym zakresie Skrypt ograniczył do prenumeraty Biuletynu Księgarstwa Spóldzielczego oraz czasopisma Spolem ${ }^{40}$.

W wyniku zaistniałej sytuacji Walne Zgromadzenie głosowało nad zlikwidowaniem Spółdzielni i przekazaniem jej majątku Kołu Prawników. Jednak wniosek ten nie otrzymał wymaganej statutowo większości 3/4 głosów. Ostatecznie przyjęto propozycję zlikwidowania Spółdzielni i przekazania poszczególnym kołom naukowym jej majątku i skryptów proporcjonalnie do pełnych opłaconych udziałów. Ponieważ postanowienie o likwidacji Spółdzielni, zgodnie ze statutem, musiało być uchwalone na dwóch kolejnych zebraniach, zwołano kolejne spotkanie na 1 października 1946 roku. Wyceniono wówczas majątek Spółdzielni (maszyny, matryce, papier, skrypty) na łączną sumę $155476 \mathrm{z}^{41}$. Ilość pełnych opłaconych udziałów wyniosła 166, z czego studenci prawa wykupili 127, studenci Wydz. Matematyczno-Przyrodniczego - 24, a Humanistycznego - 15. Odpowiadało to $76 \%, 14 \%$ i 10\% majątku Spółdzielni przeznaczonego do przekazania poszczególnym kołom naukowym.

Do rozwiązania Spółdzielni jednak nie doszło pomimo zarzutów jakie wysunięto wobec Skryptu na Walnym Zgromadzeniu w dniu 1 października 1946, a które dotyczyły opóźnień w wydawaniu podręczników, błędów rzeczowych $i$ ortograficznych w nich zawartych oraz zbyt wysokiej ceny $y^{42}$. Oskarżenie Koła Prawników, przez pozostałych członków Spółdzielni, o egoizm i dążności separatystyczne nie przeszkodziło w osiągnięciu pewnego kompromisu $^{43}$. Uchwalono wówczas wniosek o utrzymanie Skryptu i udzielenie prawnikom połowy mandatów w Radzie Nadzorczej i Zarządzie. 24 października 1946 roku na kolejnym Walnym Zgromadzeniu ${ }^{44}$ wybrano skład nowej Rady Nadzorczej oraz uchwalono, iż Spółdzielnia podejmie się dalszego wydawania skryptów pod warunkiem, że zostaną one przygotowane przez poszczególne koła naukowe, które zadbają o ich właściwy poziom merytoryczny. Pod koniec października 1946 Rada Nadzorcza powołała nowy Zarząd, w skład którego weszli tylko studenci Wydziału Prawno-Ekonomicznego: Marian Stachowiak, Alojzy Karow, Maria Bieniek i Czesław Gibas ${ }^{45}$.

Problem dalszego istnienia Spółdzielni pojawił się ponownie w grudniu tego samego roku. Rektorat Uniwersytetu M. Kopernika, po zasięgnięciu informacji w Uniwersytecie Jagiellońskim w Krakowie ${ }^{46}$, iż tamtejsze stowarzyszenie spółdzielcze Skrypt nie jest zarejestrowane jako samodzielne stowarzyszenie akademickie, ani też nie wchodzi jako sekcja 
w skład Bratniej Pomocy, zażądał legalizacji toruńskiego Skryptu jako koła akademickiego ${ }^{47}$. Sprzeciwił się temu Związek Rewizyjny uważając, że legalizacja Spółdzielni jako koła nie leży w interesie jej rozwoju i nie jest zgodna $\mathrm{z}$ jej statutem.

Porozumienie z Kołem Prawników nie trwało długo. Już z początkiem 1948 roku prawnicy rozpoczęli wydawanie skryptów z interesujących ich dziedzin we własnym zakresie ${ }^{48}$. Ponieważ była to najliczniejsza grupa studentów na toruńskiej uczelni ${ }^{49}$, w znaczny sposób wpłynęło to na rozmiary produkcji wydawniczej Akademickiej Księgarni Spółdzielczej, jednocześnie podnosząc ceny oferowanych podręczników. Starania o zcentralizowanie działalności wydawniczej w obrębie uniwersytetu nie przyniosły jednak żadnych efektów.

W organizacji Spółdzielni, od momentu separacji Koła Prawników, widać wiele zaniedbań i niedociagnięć: zaprzestano zwoływania walnych zgromadzeń, nie powołano nowego zarządu po rezygnacji studentów prawa. Według wpisów w Księdze protokółów Walnych Zgromadzeń ostatnie zebranie odbyło się 17 marca 1948 roku $^{50}$, a wybrana na nim Rada Nadzorcza funkcjonowała do 13 marca 1949, w którym to dniu odbyła ostatnie posiedzenie ${ }^{51}$. Z kolei Zarząd, wybrany uchwałą Rady Nadzorczej z 18 marca 1948 roku $^{52}$, składający się ze studentów Wydz. Prawno-Ekonomicznego bardzo szybko zaprzestał działalności. Spośród jego członków aktywnie uczestniczył w pracach Spółdzielni tylko Witold Kubisz, na którego spadło rozwiązywanie wszystkich spraw i problemów związanych z prowadzeniem Skryptu ${ }^{53}$. Sekretarz Zarządu Czesław Mreła ustapił ze swojego stanowiska już 31 sierpnia 1948, wkrótce po nim, 7 września 1948, rezygnację złożył prezes Marian Stachowiak.

\section{Finanse}

Swoje wydatki Skrypt opierał przede wszystkim na funduszu udziałowym składającym się z udziałów wykupionych przez członków. Jednak w okresie organizowania się wpływy z tego tytułu były nie wystarczające. W celu zakupu wyposażenia technicznego niezbędnego dla rozpoczęcia działalności zaciągnięto pożyczkę w Banku Gospodarstwa Spółdzielczego „Społem” w wysokości $60000 \mathrm{zł}^{54}$. Spłacono ją w miarę szybko, w przeciagu 3 miesięcy.

Działalność wydawnicza nie przynosiła zbyt wysokich zysków, zresztą Spółdzielni nie założono z myślą o osiągnięciu korzyści finansowych ${ }^{55}$. Zysk przy produkcji skryptów powyżej 100 egzemplarzy wynosił $60 \%$, przy mniejszych nakładach - nic, czasami wręcz do nich dokładano. War- 
to tu zaznaczyć, że większość podręczników wydawano w małych nakładach. Spośród 16 skryptów, które się ukazały w I półroczu 1946 roku tylko 4 (przeznaczone dla prawników) miały nakład powyżej 100 egz. W zależności od wysokości nakładów oraz od objętości podręczników ustalano ich cenę. Przy nakładach powyżej 100 egz. wyceniano 1 stronę na 1,30 zł, przy mniejszych - na 1,45 zł. Dzięki tej informacji można ustalić cenę skryptów przeznaczonych dla Wydziału Prawa na sumę 286 zł (nakłady powyżej 100 egz.), Wydz. Matematyczno-Przyrodniczego - 174 zł, Wydz. Humanistycznego - $87 \mathrm{zł}$ - nakłady poniżej 100 egzemplarzy ${ }^{56}$.

Ceny te nie byłe zbyt niskie $\mathrm{z}$ racji rozliczania kosztów produkcji na tak małe nakłady. Składała się na nie płaca maszynistek za powielanie i spinanie, płaca kierownika powielarni, płaca notujących, honoraria profesorskie oraz koszt materiałów technicznych (matryce, papier, farba). W 1945 roku wynagrodzenie pracowników wyniosło 107 162,50 zł, a honoraria profesorskie $19557 \mathrm{zł}^{57}$. Ponadto Spółdzielnia musiała uiszczać podatek obrotowy oraz wnosić odpowiednie opłaty do Związku Rewizyjnego. Dodatkowa trudność stanowił fakt, iż oferowane skrypty nie zawsze znajdowały nabywców, w wyniku czego zalegały w magazynie przynosząc Spółdzielni straty ${ }^{58}$. Pomimo tych przeszkód Akademicka Księgarnia Spółdzielcza osiągała zysk, który po wypłaceniu gratyfikacji urzędującemu Zarządowi przekazywano na fundusz zasobowy. W roku 1946 i 1947 czysta nadwyżka wynosiła łącznie 81059 zł, w 1948 - 99 165, a w 1949 - 229267 zf $^{59}$.

\section{Działalność wydawnicza Skryptu}

Po załatwieniu formalnych spraw związanych z legalizacją Spółdzielni i jej władz ${ }^{60}$ przystapiono do realizowania zasadniczego celu jakim było wydawanie skryptów. W tym celu zakupiono dwa powielacze i 3 maszyny do pisania, zaangażowano personel do działu technicznego ${ }^{61}$. Opracowano skrypty dla Wydziału Prawniczego, Humanistycznego i Matematyczno-Przyrodniczego przede wszystkim toruńskiego uniwersytetu, chociaż otrzymano zamówienia również z innych uczelni ${ }^{62}$. Niestety nie udało się ustalić, które ze szkół wyższych zwróciły się z tą prośbą. Zagadnienie rozpowszechniania skryptów poza terenem Torunia powróciło w 1948 roku. Wówczas władze Spółdzielni podjęły się rozprowadzania swoich wydawnictw na innych uczelniach, min. w Szczecinie ${ }^{63}$.

Proces wydawniczy przebiegał następująco: Spółdzielnia zlecała studentom dostarczanie tekstów wykładów ${ }^{64}$, które po skorygowaniu przez wykładowców były przepisywane maszynowo na matrycach, powielane i ewentualnie broszurowane w introligatomi. Notowaniem, przepisywaniem 
na matrycach i powielaniem zajmowali się studenci wynagradzani akordowo od strony druku ${ }^{65}$. Początkowo również spinanie skryptów wykonywano we własnym zakresie, polegało ono na łączeniu bloku przy pomocy trzech metalowych zszywek. W późniejszym czasie czynności te zlecano zawodowenu introligatorowi. Zajmował się tym Marian Szulc ${ }^{66}$, właściciel zakładu założonego w 1936 roku, wykonującego prace dla urzędów, bibliotek i szkó ${ }^{67}$, przyszły kierownik drukarni uniwersyteckiej.

W 1946 roku szczególną aktywnością wykazali się studenci Wydziału Prawno-Ekonomicznego przygotowując największą ilość skryptów ${ }^{68}$. Opracowali oni wykłady z następujących przedmiotów: historię socjologii Tadeusza Szczurkiewicza, historię ustroju Polski Zbigniewa Wojciechowskiego, teorię prawa oraz filozofię prawa Eugeniusza Bautro, historię prawa na zachodzie Europy Karola Koranyi'ego, prawo międzynarodowe Władysława Namysłowskiego, prawo administracyjne oraz naukę administracji Witolda Reissa. Dodatkowo przygotowano teksty wykładów z ekonomii Witolda Olszewskiego, teorii kryzysu Adolfa Tokarskiego, prawa handlowego Stefana Buczkowskiego, nauki skarbowości oraz prawa skarbowego Leona Kurowskiego.

Dla Wydziału Matematyczno-Przyrodniczego Spółdzielnia wydała skrypt z logiki matematycznej Stanisława Jaśkowskiego. Ponadto opracowano teksty wykładów z anatomii człowieka, neurofizjologii, chemii ogólnej oraz zoologii. Nie podano jednak autorów skryptów, co utrudnia zidentyfikowanie tych publikacji. Pewnym rozwiązaniem jest ustalenie nazwisk kierowników poszczególnych katedr, ponieważ to oni w większości wypadków prowadzili wykłady. Kierownikiem Katedry Anatomii Człowieka i Higieny Szkolnej był Witold Sylwanowicz, który w 1947 roku odszedł na stanowisko profesora Akademii Medycznej w Gdańsku ${ }^{69}$. Opracował on podręcznik dla średnich szkół medycznych pod tytułem Anatomia i fizjologia czlowieka, który ukazał się w Warszawie w 1957 roku. Możliwe zatem, że to jego autorstwa jest skrypt $\mathrm{z}$ anatomii wydany przez Księgarnię Akademicką. Niestety w przypadku pozostałych przedmiotów nie udało się ustalić zbyı wiele faktów. Katedrą Neurofizjologii i Fizjologii Porównawczej, jedną z pierwszych tego typu w Polsce, kierowała Janina Hurynowicz, natomiast Katedrą Zoologii Systematycznej - Jan Prüffer ${ }^{70}$, z kolei Katedra Chemii obsadzona była przez Witolda Zacharewicza ${ }^{71}$. Jednak żadna z tych osób nie jest autorem pracy choć w przybliżeniu odpowiadającej skryptom przygotowanym przez Spółdzielnię. 
Studenci Wydziału Humanistycznego w 1946 roku opracowali wykłady z następujących przedmiotów: filozofii (w 4 częściach) oraz gramatyki starocerkiewnej. Dodatkowo przygotowano także teksty filozoficzne. W tym okresie na toruńskiej uczelni pracował Tadeusz Czeżowski, który zorganizował Katedrę Filozofii oraz jego najbliższy współpracownik Henryk Elzenberg. Katedrą Filologii Słowiańskiej kierował przejściowo Witold Taszycki, a później Stanisław Urbańczyk ${ }^{72}$. Nie udało się jednak ustalić, które z powyższych osób były autorami poszczególnych tekstów.

Ogółem w 1946 roku wydano 13 skryptów dla Wydziału Prawno-Ekonomicznego, 3 dla Wydziału Humanistycznego i 5 dla Wydziału Matematyczno-Przyrodniczego. Nakład poszczególnych tytułów był różny i wahał się od 290 (teoria prawa) do 28 (logika matematyczna) egzemplarzy. Wynikato to z liczebności studentów poszczególnych wydziałów i ich członkostwa w Księgarni Spółdzielczej, stąd skrypty prawnicze przeznaczone dla najliczniejszej grupy wydawane były w największym nakładzie.

W latach 1947-1948 dział wydawniczy Akademickiej Księgarni Spółdzielczej przygotował 7 skryptów w 12 zeszytach ${ }^{73}$. Dla studentów Wydziału Prawa Historię ustroju na Zachodzie Europy K. Koranyi'ego w dwóch częściach i nakładzie 200 egzemplarzy, dla studentów Wydziału Matematyczno-Przyrodniczego dwa tomy Chemii nieorganicznej opracowanej przez Antoniego Basińskiego (w 423 egz.), podręczniki z matematyki cz. I i II w 100 egz., myologię - 205 egz., osteologię - 102 egz., logikę matematyczną - 202 egz. Dwie części Umystowości Średniowiecza Karola Górskiego w nakładzie 105 egz. przeznaczone były dla studentów Wydziału Humanistycznego ${ }^{74}$.

Ponieważ od początku roku 1948 Koło Prawników podjęło się samodzielnego wydawania skryptów z własnej dziedziny, Spółdzielnia skupiła się na wypełnianiu swoich zadań w stosunku do pozostałych wydziałów i związanych z nimi kół naukowych ${ }^{75}$. W związku z tym iż były one mniej liczne, wzrosły ceny oferowanych podręczników (niskie nakłady i różne wzory). Wpłynęło to ujemnie na rozwój gospodarczy Spółdzielni.

Próby ustalenia produkcji wydawniczej Skryptu po odejściu prawników napotkały na szereg przeszkód. W sprawozdaniach z tego okresu brak informacji o ilości przygotowanych podręczników oraz o tym jakie wykłady opracowano. Dodatkowy problem stanowił fakt, iż nie zawsze zachowały się strony tytułowe co uniemożliwiło ustalenie roku wydania ${ }^{76}$. Ponadto niskie nakłady (czasami nawet tylko 20 egz.) sprawiły, że część tych skryptów nie trafiła do Biblioteki Głównej UMK lub w ogóle się nie zachowa- 
ła. Niemniej można stwierdzić, iż w 1949 ukazał się kolejny tom Chemii A. Basińskiego, Zasady ustroju administracji państwa polskiego Wacława Brzezińskiego oraz pierwszy zeszyt Prawa podatkowego, autorstwa byłego przewodniczącego Koła Prawników, Z. Jaśkiewicza.

W roku 1950, w związku z likwidacją Spółdzielni i przekazaniem wyposażenia technicznego Komitetowi Środowiskowemu FPOS w Toruniu, ukończenie druku rozpoczętych skryptów powierzono Zakładom Graficznym Państwowych Zakładów Wydawnictw Szkolnych w Lodzi. Wydano w ten sposób drugi zeszyt Prawa podatkowego Z. Jaśkiewicza i Historię skarbowości oraz Historię nauki skarbowości Leona Kurowskiego.

Akademicka Księgarnia kierowała się zasada oszczędności. Skrypty wydawano w większości bez okładek, w formacie wielkości papieru maszynowego (21 x 29,7 cm). Tekst odbijano najczęściej dwustronnie (zależało to od papieru jakim dysponowała Spółdzielnia) metodą powielania. Biorąc pod uwagę fakt, iż w dokumentach pojawiają się stwierdzenia o zakupie bądź koszcie matryc, przypuszczalnie wykorzystywano technikę powielania woskówkowego. Powielacz tego typu wymagał napisania tekstu na matrycy sporządzonej ze specjalnego papieru pokrytego warstwą wosku. W miejscach uderzeń czcionek maszyny do pisania farba przenikała i w zetknięciu z czystym arkuszem papieru dawała odbitkę ${ }^{77}$. W ten sposób uzyskiwano tekst główny, natomiast wykonanie kart tytułowych zlecano drukarniom, m.in Toruńskim Zakładom Graficznym.

Spółdzielnia wykorzystywała dwa warianty kart tytułowych. W pierwszym u góry karty tytułowej zamieszczano nazwisko autora skryptu. Informację tą od umieszczonego pośrodku tytułu oddzielała pozioma linia. Tuż poniżej tytułu zaznaczano, iż podręcznik ukazywał się na prawach rękopisu. Zamieszczano również informacje o tym, które z kół naukowych przygotowało poszczególne teksty wykładów. U dołu karty tytułowej po podwójnej poziomej linii umieszczano tekst Akademicka Księgarnia Spółdzielcza Skrypt oraz miejsce i rok wydania.

W drugim wariancie przyjęto odmienny układ powyższych elementów. U góry umieszczano tytuł, poniżej występował zwrot „skrypt z wykładów” wraz z nazwiskiem wykładowcy. Następnie zaznaczano miejsce i rok wydania. Pozioma linia (podwójna lub pojedyncza) poprzedzała tekst Akademicka Księgarnia Spółdzielcza Skrypt.

Warto zaznaczyć, że informacja o wydawcy często w ogóle nie występuje (np. E. Bautro, Historia filozofii prawa, Toruń 1946) lub jest zastąpiona przez nazwę poszczególnych kół naukowych (np. K. Koranyi, Historia ustroju 
na Zachodzie Europy, Toruń: Koło Prawników Studentów UMK, 1947) co przysparza trudności w ustaleniu produkcji wydawniczej Spółdzielni.

Od strony estetycznej wydawnictwa Skryptu nie przedstawiają się najlepiej. Aby zaoszczędzić papier, tekst pisany był bez odstępów, co utrudnia jego odczytanie. Maszynopisy, który służyły za matryce były zazwyczaj lekko rozmazane, a w miarę odbijania kolejnych kopii czytelność tekstu jeszcze się pogarszała. Dodatkowo technika, jaką wykorzystywano do powielania, utrudniała zamieszczanie ilustracji.

\section{Papier}

Do produkcji skryptów Spółdzielnia używała przede wszystkim papieru cyklostylowego, który pozwalał na dwustronne odbijanie tekstu. W przypadku korzystania $z$ innych gatunków, odbijano jednostronnie, a tym samym dwukrotnie wzrastało zapotrzebowanie. Pierwsze zapasy papieru potrzebne do produkcji zakupiono na wolnym rynku ${ }^{78}$. Jego rezerwy musiały być dość znaczne skoro w lutym 1946 roku w Alma Mater Thorunensis zapewniano czytelników, iż „nie grozi obecnie możliwość przerwania pracy z powodu braku papieru"79. Niemniej Zarząd czynił wiele starań, aby taka sytuacja nie miała miejsca. Już w styczniu 1946 roku zwrócono się z prośbą do Rektora Uniwersytetu M. Kopernika o pomoc w uzyskaniu papieru na wydawnictwa, rozprawy, sprawozdania itp. w roku akademic$\operatorname{kim} 1946 / 47^{80}$. Zapotrzebowanie określono na około 120 tys. arkuszy wymiaru gazetowego. Niezależnie od tego Spółdzielnia, przewidując wzrost liczby studiujących w następnym roku akademickim, poprosiła o przydział 1,5 miliona arkuszy papieru do powielaczy.

W lutym 1946 roku Zarząd Związku Studentów Bratniej Pomocy zwrócił się, w imieniu wydawnictwa Skrypt, do Centrali Zaopatrzenia i Zbytu Przemysłu Papierniczego przy Ministerstwie Przemysłu w Łodzi o przydział papieru cyklostylowego ${ }^{81}$. Niestety nie wiadomo jaka była odpowiedź w tej sprawie.

Pozytywnie na prośby Zarządu Skryptu zareagował dyrektor Państwowych Zakładów Wydawnictw Szkolnych, dr Stanisław Pazyra, przyszły autor pracy dokumentującej losy polskiej książki w czasie II wojny światowej ${ }^{82}$, który poprosił o dokładne podanie ilości potrzebnego papieru ${ }^{83}$. Spółdzielnia poinformowała wówczas, że jej miesięczne zapotrzebowanie wynosi 80000 znormalizowanych arkuszy papieru cykostylowego. $Z$ pomocy Państwowych Zakładów Wydawnictw Szkolnych korzystano niejednokrotnie. W listopadzie 1946 roku Zarząd Bratniej Pomocy zwrócił się z prośbą o odstapienie na rzecz studentów pewnej ilości przydziałów z Fabryki Celu- 
lozy we Włocławku ${ }^{84}$. Uzyskany w ten sposób papier miał być przeznaczony na produkcję skryptów oraz na wydanie kolejnych numerów miesięcznika akademickiego Alma Mater. Przypuszczalnie Zarząd Bratniej Pomocy nie był pewny jaki skutek odniesie jego prośba, skoro w tym samym miesiącu skierował pismo o podobnej treści do Centralnego Zarządu Przemysłu Papierniczego w Łodzi ${ }^{85}$.

Szeroko zakrojone poszukiwania przydziałów papieru spotykały się często z pozytywnym oddźwiękiem. W grudniu 1946 roku Bratnia Pomoc otrzymała z Ministerstwa Oświaty, na potrzeby wydawnicze Skryptu, $500 \mathrm{~kg}$ papieru cyklostylowego ${ }^{86}$. Z początkiem czerwca 1947 roku zażądano bardzo dokładnych rozliczeń z tego przydziału, z podaniem ilości stronic, formatu wykonanych druków oraz dołączeniem egzemplarzy okazowych powielonych skryptów ${ }^{87}$.

\section{Wyposażenie techniczne}

Pierwsze elementy wyposażenia technicznego nabyto 20 grudnia 1945 roku ${ }^{88}$, składały się na nie: trzy maszyny do pisania różnego typu („Triumph” - cena $5000 \mathrm{zł}$, „Urania” - cena $6500 \mathrm{zł}$ oraz „Regina” - cena $6000 \mathrm{zł}$ ), powielacz o wartości $4000 \mathrm{zł}$ oraz powielacz typu „Roto”, który nabyto za sumę $13000 \mathrm{zł}$. Dodatkowo w 1946 roku zakupiono za kwotę $6000 \mathrm{zł}$ zszywacz potrzebny do broszurowania skryptów ${ }^{89}$. W 1949 roku Spółdzielnia Skrypt posiadała na wyposażeniu technicznym już 3 powielacze oraz 2 zszywacze, których łączna cena nabycia wynosiła $73475 \mathrm{z}^{90}$.

\section{Dzialalność księgarska}

Do marca 1947 roku działalność handlowa Skryptu ograniczała się do sprzedaży wyprodukowanych podręczników ${ }^{91}$. Początkowo odbywała się ona wyłącznie w biurze Spółdzielni. Jednak stopniowo zamierzano rozszerzyć działalność księgarską na większą skalę ${ }^{92}$ Już w listopadzie 1946 r. planowano zaopatrzenie sklepu w potrzebne wyposażenie (półki, stoły), nawiązanie kontaktów z księgarniami wydawniczymi i hurtownikami materiałów piśmienniczych. Zgłoszono akces do Związku Księgarzy Polskich, co stwarzało możliwość sprowadzania podręczników po niższych cenach ${ }^{93}$. Ostatecznie Skrypt został przyjęty do tego stowarzyszenia w marcu 1947 roku, po wcześniejszym potwierdzeniu respektowania praw autorskich ${ }^{94}$.

W marcu 1947 w holu Domu Akademickiego nr 1 zamontowano kiosk do którego przeniesiono sprzedaż. Wraz z nowym pomieszczeniem rozszerzył się asortyment oferowanych artykułów. Rozpoczęto sprzedaż materiałów i przyborów piśmienniczych oraz prasy, m.in. miesięcznika Alma 
Mater Thorunensis ${ }^{95}$. Obroty w 1946 roku wynosiły przeciętnie $27500 \mathrm{zl}$, a w 1947 - 30 200. Lustrator Zwiazku Rewizyjnego Wincenty Wieczorek uznał je za małe, dopatrując się przyczyny takiego stanu rzeczy między innymi w szczupłym asortymencie oferowanych towarów. W tym okresie Spółdzielnia zaopatrywała się w materiały piśmiennicze w Państwowej Centrali Handlowej oraz w „Społem"96. Były to przede wszystkim zeszyty, bruliony, pocztówki, ołówki, papeterie, bloki korespondencyjne ${ }^{97}$. Dodatkowo asortyment rozszerzono o wydawnictwa obce, oferując podręczniki z zakresu prawa, astronomii, matematyki oraz pozycje dokumentujące dokonujące się przemiany polityczne. Do wydawnictw tych należy zaliczyćc ${ }^{98}$ K. Marks, F. Engels Manifest komunistyczny, Warszawa 1946; M. Bogolepow, Radziecki system finansowy, Warszawa 1948; A. Świątkowski, Wyznaniowe prawo państwowe; M. Rogalski, Studium uniwersyteckie nauki o Polsce $i$ świecie wspótczesnym. Wyklady na Uniwersytecie Warszawskim... w r. akad. 1948/49, Cz. 1 - 2, Warszawa 1948; F. Zoll, Prawo cywilne w zarysie opracowane przy współudziale Adama Szpunara, T. 1 - 5, Kraków 1946 - 1948; przepisy prawne publikowane w ramach serii Biblioteka Tekstów Ustaw pod redakcją Władysława Kufla (Poznań: Centrala Wydawnicza sp. z oo., 1947-1948); R. Kunze, Zoologia Cz. I Ogólna; W. Pogorzelski, Zarys teorii elektryczności i magnetyzmu, Warszawa 1947; W. Zonn, Astronomia ogólna, Warszawa 1949; L. Czerski, Tablice do analizy chemii jakości; J. Jodłowski, Z. Kapitaniak, Prawo i wymiar sprawiedliwości w okresie budowy podstaw socjalizmu, Warszawa 1949; L. Chajn, Trzy lata demokratyzacji prawa i wymiaru sprawiedliwości, Warszawa 1947; Tenże, Inteligencja polska wobliczu dokonujacych się przemian spolecznych, Warszawa 1949; W. Karpiński, Jak rzqdzi się Zwiqzek Radziecki, Warszawa 1949; B. Wojtowicz, Kto i jak rządzi w Polsce, Warszawa 1948; W. Pogorzelski, Zarys rachunku prawdopodobieństwa i teorii blędów, Warszawa 1948; Z. Kraczkiewicz, Cytologia ogólna, Warszawa 1949.

We wrześniu 1949 roku Spółdzielnia zamierzała rozszerzyć swoją działalność księgarska, w związku z tym ubiegała się o zezwolenie na otwarcie sklepu w mieście ${ }^{99}$. Jednak toruńska Centrala Spółdzielni Wydawniczych i Księgarskich podeszła do tego zagadnienia niezbyt przychylnie obawiając się o opłacalność całego przedsięwzięcia i sugerując władzom Skryptu skupienie się nad zcentralizowaniem działalności wydawniczej na terenie Uniwersytetu M. Kopernika. Wkrótce sprawa ta straciła na znaczeniu w związku z likwidacją Spółdzielni. 


\section{Lokale}

Siedzibą Akademickiej Księgarni Spółdzielczej Skrypt był Dom Akademicki przy ul. Mickiewicza $2 / 4$. Spółdzielnia zajmowała tam usytuowany na parterze pokój nr 10-11 ${ }^{100}$, w którym mieściło się biuro oraz prowadzono sprzedaż skryptów ${ }^{101}$. W listopadzie 1947 roku Spółdzielnia posiadała już dwa pokoje, w jednym nadal znajdowało się biuro i magazyn, w drugim powielarnia i maszyny do pisania ${ }^{102}$. Wincenty Wieczorek, który $z$ ramienia Związku Rewizyjnego przeprowadzał lustrację w listopadzie 1947 roku, zarzucił Spółdzielni brak odpowiednich sprzętów biurowych do przechowywania dokumentów i akt, co obniżało sprawność biura.

W celu poszerzenia asortymentu oraz usprawnienia obsługi studentów Spółdzielnia zdecydowała się sfinansować budowę drewnianego kiosku w hallu domu akademickiego ${ }^{103}$. Prace budowlane wykonał stolarz Bratniej Pomocy, a koszt całego przedsięwzięcia wyniósł w sumie 6786 zł. Podsumowując Spółdzielnia dysponowała lokalem biurowym o powierzchni $20 \mathrm{~m}^{2}$, kioskiem w którym prowadzono sprzedaż o powierzchni $7,5 \mathrm{~m}^{2}$ oraz $20 \mathrm{~m}^{2}$ pomieszczenia przemysłowego przeznaczonego na powielarnię $e^{104}$.

\section{Pracownicy}

Pod koniec 1945 roku Spółdzielnia, przygotowując się do rozpoczęcia działalności wydawniczej zatrudniła pierwszych pracowników ${ }^{105}$. Początkowo była to jedna maszynistka, studentka prawa Irena Radłowska oraz dwóch pracowników powielarni: student matematyki Janusz Irka oraz student prawa Jerzy Kasprzykowski. Na przełomie 1945/46 roku Skrypt potrzebował już drugiej maszynistki. Została nią Adela Styczyńska. Po paru miesiącach, na wiosnę 1946 roku odeszła ze Spółdzielni, ponieważ otrzymała stanowisko asystentki w katedrze Filologii Angielskiej.

W lutym tego roku w dziale technicznym było zatrudnionych już osiem osób - studentów i studentek ${ }^{106}$. Halina Swiniarska, Dejewska ${ }^{107}$ oraz Irena Radłowska zajmowały się przepisywaniem wykładów z wynagrodzeniem 9 zł od matrycy. Janusz Irka, Mieczysław Bacela oraz Jerzy Kasprzykowski, zatrudnieni przy powielaniu, otrzymywali 6 groszy od kartki. Korektę matryc przeprowadzał Czesław Gibas otrzymując 1,5 zł od strony, który jednocześnie od początku listopada do 19 grudnia 1946 roku sprawował funkcję kierownika działu wydawniczego. Posadę tę objął po nim Henryk Jabłoński, student Wydz. Matematyczno-Przyrodniczego ${ }^{108}$. Broszurowanie skryptów powierzono studentce tego samego wydziału, Halinie Kłosowskiej, która zarabiała 8 zł za godzinę spinania ${ }^{109}$. Dodatkowo Spółdzielnia zatrudniła skarbnika Zarządu, Alicję Żukowską do prowadzenia księgowości oraz sprzedaży podręczników z pensją 2000 zł. 
Od roku 1947 ograniczono liczbę osób zatrudnionych w Spółdzielni do trzech: ekspedientki sklepowej, buchaltera czyli księgowego oraz pracownika powielarni ${ }^{110}$.

Od marca 1947 roku Spółdzielnia zatrudniła w kiosku, początkującą w tym zawodzie i branży, sprzedawczynię ${ }^{111}$. Otrzymywała ona wynagrodzenie w wysokości 3000 zł miesięcznie oraz obiady w stołówce, których koszt wynosił 1200 zł. Przypuszczalnie osobą ta była Elżbieta Luckner wymieniona w protokole polustracyjnym z 1949 roku jako ekspedientka z dwuletnia już praktyką o powyższym wynagrodzeniu ${ }^{112}$. Od stycznia 1949 roku podniesiono jej pensję do wysokości $6000 \mathrm{z}^{113}$.

W dziale technicznym Spółdzielni w okresie jej największego rozkwitu zatrudnionych było osiem osób. Jednak w wyniku separacji Koła Prawników i prowadzenia przez to koło samodzielnej działalności wydawniczej stopniowo spadała liczba osób zajmujących się powielaniem skryptów. W styczniu 1948 roku jako pracownika wytwórni zatrudniono już tylko Sylwestra Gawrońskiego ${ }^{114}$, ale za to w wymiarze 8 godzin dziennie. Wynagrodzenie ustalono według systemu akordowego płacąc za każdą powieloną stronę po 9 groszy oraz za składanie skryptów po 43 zł za godzinę. Pensję wypłacano zaliczkowo na końcu każdego miesiąca $\mathrm{z}$ rozliczeniem po ukończeniu produkcji skryptu.

Jak już było wspomniane w początkowym okresie księgowość Spółdzielni prowadziła Alicja Żukowska. Stopniowo jednak w miarę rozszerzania działalności Spółdzielni prawdopodobnie jej wiedza z zakresu buchalterii była nie wystarczająca. W maju 1947 roku zatrudniono Franciszka Gomułę zobowiązując go do prowadzenia księgowości z pensją $3000 \mathrm{zł}$ miesięcznie ${ }^{115}$. Polecono mu także, za dodatkowym wynagrodzeniem 6000 zł, uporządkować księgi za okres od 1 stycznia do 30 kwietnia 1947 roku. Umowa o pracę była zawarta do końca czerwca, później jej nie przedłużono. Przypuszczalnie w okresie wakacyjnym nie prowadzono żadnej działalności, stąd brak zapotrzebowania na tego typu usługi. Jednak już od września 1947 Księgarnia Spółdzielcza posiadała nowego księgowego, Henryka Mrełę oferując mu wynagrodzenie $3000 \mathrm{zł}$ miesięcznie ${ }^{116}$. Pensję w tej samej wysokości wypłacano Barbarze Tarlachównie za prowadzenie rachunkowości w 1948 roku $^{117}$.

W okresie likwidacji Spółdzielnia zawarła umowę z mgr Karolem Łutowiczem zamieszkałym w Toruniu na ul. Bydgoskiej $14^{118}$. Powierzono mu prowadzenie księgowości przez okres likwidacji Skryptu oraz zobowiązano do zamknięcia ksiąg i sporządzenia odpowiedniego bilansu. Umowę zawarto 
na czas od 1 stycznia do czerwca 1951 z wynagrodzeniem $100 \mathrm{zł} \mathrm{miesięcz-}$ nie za 6 godzin pracy w tygodniu. W związku z przeciaganiem się procesu likwidacyjnego umowę przedłużono na dalsze 7 miesięcy, do dnia 31 stycznia 1952 roku. Ostatnią osobą zatrudnioną na tym stanowisku był Czesław Sarecki, prowadzący rachunkowość Skryptu co najmniej do 17 marca 1952 roku z pensją 100 zł miesięcznie ${ }^{119}$.

W pierwszym okresie istnienia Skryptu zatrudniano przede wszystkim studentów. Stopniowo jednak posady w Spółdzielni otrzymywały osoby nie związane z uczelnią. Wpływ na ten fakt miała zapewne zmiana organizacji toku studiów wprowadzona w roku akademickim 1949/50 (tzw. dyscyplina studiów), która zobowiązywała nowo przyjętych studentów do uczestnictwa w ściśle określonych zajęciach i terminowego zdawania egzaminów, co ograniczało ich aktywność społeczną i kulturalną ${ }^{120}$. Poza tym wiele osób wycofujących się z pracy w Skrypcie czyniło to z przyczyn zawodowych. Otrzymali oni stanowiska naukowe na uczelni, np.: Marian Kryszewski, Władysław Chodkiewicz - asystenci w Katedrze Chemii Nieorganicznej, Adela Styczyńska - asystentka w Katedrze Filologii Angielskiej, Tadeusz Cieślak - adiunkt na Wydziale Prawa, sekretarz i dyrektor administracyjny Uniwersytetu M. Kopernika w latach 1948-1949121.

\section{Likwidacja}

Pomimo pewnych zaniedbań organizacyjnych Spóldzielnia funkcjonowała normalnie przygotowując kolejne wydawnictwa. Jej rozwiązanie związane było z rozpoczęciem propagandy ideologicznej, tzw. „bitwy o handel”, skierowanej przeciwko własności prywatnej, a tym sanym przeciwko spółdzielczości, którą uznano za formę przedsiębiorczości kapitalistycznej ${ }^{122}$. Pierwszym etapem była reorganizacja dotychczasowej struktury spółdzielczości. Do 1948 roku pod względem rewizyjnym i gospodarczym, stanowiły ją dwie organizacje: Związek Rewizyjny Spółdzielni Rzeczpospolitej Polskiej oraz „Społem” Związek Gospodarczy Spółdzielni R.P. 21 maja 1948 roku Sejm uchwalił ustawy o Centralnym Związku Spółdzielczym oraz o centralach spółdzielczo-państwowych na mocy których powstało 8 central, wśród nich Centrala Spółdzielni Wydawniczych i Księgarskich ${ }^{123}$. Kolejnym krokiem było zebranie Rady Nadzorczej CSWiK z dnia 11 paździemika 1949 roku, na którym podjęto decyzję o likwidacji spółdzielni, których istnienie zostanie uznane jako niecelowe ${ }^{124} .5$ listopada 1949 roku spółdzielnię Skrypt zakwalifikowano jako zbędną ${ }^{125}$, a ekspozytura CSWiK w Toruniu już 10 listopada 1949 r. zaleciła jej likwidację. W tym okresie Zarząd od dłuższego czasu był zdekompletowany ${ }^{126}$, spośród jego członków aktywnie działał jedynie mgr Witold Kubisz. 
Również Prezydium Rady Naczelnej Federacji Polskich Organizacji Studenckich (FPOS) pismem z dnia 17 grudnia 1949 roku oraz z dnia 30 grudnia 1949 wezwało Komitet Środowiskowy FPOS w Toruniu do spowodowania zwołania Walnego Zgromadzenia członków Skryptu w celu powzięcia obowiązujących uchwał o rozwiązaniu i likwidacji Spółdzielni oraz przekazania wszystkich urządzeń technicznych na rzecz Państwowych Zakładów Wydawnictw Szkolnych. Skrypty i pozostałe pomoce naukowe miał przejąć bezpłatnie Komitet Środowiskowy FPOS w Toruniu wraz z wszelkimi zobowiązaniami i należnościami Spółdzielni.

Walne Zgromadzenie nie doszło do skutku z przyczyny „nikłego zainteresowania członków Spółdzielni”, które można uznać za próbę biernego oporu. Niemniej Zarząd w osobie Witolda Kubisza dostosował się do zarządzeń Centrali Spółdzielni Wydawniczych i Księgarskich oraz Rady Naczelnej FPOS 127. 28 lutego 1950 roku przekazano wyposażenie techniczne (3 maszyny do pisania, 2 powielacze), będące prawną własnością Akademickiej Księgarni Spółdzielczej „,Skrypt”, Komitetowi Środowiskowemu FPOS w Toruniu w osobach Kazimierza Wajdy, przyszłego profesora Uniwersytetu M. Kopernika oraz Ireneusza Olszty. Od tego momentu Spółdzielnia wstrzymała działalność wydawniczą, w związku z czym poniosła straty z powodu niemożności wykończenia rozpoczętych prac nakładczych skryptów uniwersyteckich ${ }^{128}$. Straty te w lutym 1952 roku stanowiły sumę 7832,76 zł.

30 stycznia 1950 roku Centrala Spółdzielni Wydawniczych i Księgarskich wystapiła do Centralnego Związku Spółdzielczego z wnioskiem o rozwiązanie Akademickiej Księgarni Spółdzielczej ${ }^{129}$. W międzyczasie, gdy Komitet Uczelniany Zrzeszenia Studentów Polskich (przemianowany z Komitetu Środowiskowego FPOS) z braku odgórnych zarządzeń ze strony Rady Naczelnej, nie przejął pozostałego majątku Spółdzielni (tzn. podręczników i materiałów piśmienniczych), Skrypt rozpoczął likwidację tego majątku bez formalnego rozwiązania spółdzielni ${ }^{130}$. Jednocześnie pismem z dnia 29 sierpnia 1950 powiadomiono Centralny Związek Spółdzielczy o zaprzestaniu działalności gospodarczej, a w kolejnym z dnia 25 października o braku aktywności Zarządu. W związku z tym Sąd Powiatowy w Toruniu 22 maja 1951 roku postanowił wpisać do Rejestru Spółdzielni decyzję o rozwiązaniu Akademickiej Księgarni Spółdzielczej Skrypt na podstawie orzeczenia Centralnego Związku Spółdzielczego z 11 kwietnia 1951 roku i wpisu tego dokonał 29 maja 1951 roku $^{13 !}$. Likwidatorem ustanowiono jedynego czynnego członka Zarządu, Witolda Kubisza. Ogłoszenie o rozwiązaniu 
Spółdzielni zamieszczono w Monitorze Spóldzielczym nr 10 z dnia 15 lipca 1951 , wzywając wierzycieli do zgłoszenia ewentualnych roszczeń w terminie 6 miesięcy od daty ogłoszenia ${ }^{132}$.

Zakończenie likwidacji Spółdzielni uzależnione było od Rady Naczelnej ZSP, która jako instancja zobowiązana do zapłaty za przejęty majątek, usiłowała się uchylić od uregulowania należności, uniemożliwiając w ten sposób zakończenie likwidacji z braku środków finansowych ${ }^{133}$. Ostatecznie Centralny Związek Rewizyjny, uchwałą z dnia 7 kwietnia, postanowił połączyć Skrypt ze Spółdzielnią Księgarską „Światowid” w Warszawie - również w likwidacji, która protokołem z dnia 6 i 7 maja 1952 roku przejęła Akademicką Księgarnię Spółdzielczą i zakończyła jej likwidację.

Na działalność wydawniczą Akademickiej Księgarni Studenckiej składała się produkcja przydatnych studentom skryptów uniwersyteckich, najczęściej autorstwa wykładowców UMK. Pozostałe prace naukowe i monografie pracowników toruńskiej uczelni ukazywały się nakładem Księgarni Naukowej T. Szczęsnego ${ }^{134}$. Po likwidacji tych dwóch instytucji wydawniczych ich funkcje przejęło - współpracujące z Uniwersytetem M. Kopernika - Państwowe Wydawnictwo Naukowe, a od 1956 roku nowo utworzone wydawnictwo uniwersyteckie.

* Wydawnictwa Akademickiej Księgarni Spółdzielczej Skrypt

1c. Ajdukiwicz Kazimierz, Filozofia (wyjątki)

2c. Anatomia

3a. Basiński Antoni, Chemia nieorganiczna i ogólna, T. I : Torun [b. r. wyd.]. - 226 s.; T. II : Toruń 1949 . - 263 s.; T. III : Toruń 1948 . - 210 s.; T. IV : Toruń 1949 . - 244 s. (BG UMK 245646)

4a. Bautro Eugeniusz, Historia filozofii prawa, Toruń 1946. - [2], 151 s. (BG UMK 245808)

5c. Bautro Eugeniusz, Teoria prawa

6c. Brzeziński Wacław, Uzupetnienie do planowania gospodarczego

7a. Brzeziński Wacław, Zasady ustroju administracji państwa polskiego wedlug wykladów... . - Wyd. trzecie. - Toruń 1949 . - [2], 109 s. (BG UMK 308503)

8c. Buczkowski Stefan, Prawo handlowe

9c. Dochody P.K.P.

10c. Dochody z odplatnej dzialalności państwa

11c. Embriologia 
12a. Górski Karol, Umystowość Średniowiecza. Cz. I : Toruń 1947. - [2], 88 s.; Cz. II: Toruń 1948 . - [2], 51 s. (BG UMK 201883)

13c. Gramatyka języka starocerkiewnego

14a. Jaśkiewicz Zbigniew, Prawo podatkowe. Skrypt z wykładów... Z. I: Toruń 1949 . - [2], 68 s.; Z. II: Torun 1950 (druk.: Łódź : Zakłady Graficzne Państw. Zakładów Wydawnictw Szkolnych) . - [2], 69 - 123, [2] s. (BG UMK 542904)

15b. Jaśkowski Stanisław, Elementy logiki matematycznej. - Toruń 1947

16c. Jeśmianowicz Leon, Rachunek różniczkowy i całkowy

17c. Karwowski Otton, Myologia

18a. Koranyi Karol, Historia ustroju na Zachodzie Europy. Skrypt z wykladów.., Toruń 1947 cz. I : . - [2], 78 s.; cz. II: . - [2], 79 - 249 s. (BG UMK 245765)

19a. Kurowski Leon, Historia skarbowości oraz historia nauki skarbowości. Skrypt z wykladów..., Toruń 1950 (druk.: Łódź: Zakłady Graficzne Państw. Zakładów Wydawnictw Szkolnych) . - [2], 43 s. (BG UMK 571216)

20a. Kurowski Leon, Teoria skarbowości na podstowie wykladów..., [b. m. wyd.] [b. r. wyd.] Z. 1: pierwszy trymestr . - [2], 75 s.; Z. 2 . - [2], 112 s. (BG UMK 245810)

21c. Mancewicz Eugeniusz, Medycyna sadowa

22c. Namysłowski Władysław, Prawo międzynarodowe

23a. Namysłowski Władysław, Prawo narodów. Skrypt wg. wykladów... Cz I : Toruń 1946 . - [2], 81 s.; Cz II : Toruń 1947 . - [2], 82 - 222 s. (BG UMK 242346)

24a. Namysłowski Władysław, Zarys międzynarodowego prawa prywatnego. Skrypt wg. wykladów..., Toruń 1947 . - [2], 64 s. (BG UMK 245877)

25c. Neurofizjologia

26c. Olszewski Witold, Ekonomia

27c. Osteologia

28c. Reiss Witold, Nauka administracji

29c. Reiss Witold, Prawo administracyjne

30c. Statuty organizacyjne

31a. Szczurkiewicz Tadeusz, Historia socjologii. Z. 1: [br. m. wyd.] [br. r. wyd.] . - 26 s. (BG UMK 242329)

32c. Tokarski Adolf, Teoria kryzysu

33c. Wojciechowski Zbigniew, Historia ustroju Polski

34c. Zoologia

* Litera „a” oznacza pozycje zidentyfikowane z autopsji, przy ich opisie 
podana jest sygnatura Biblioteki Głównej Uniwersytetu M. Kopernika. Litera „b" oznacza pozycje zidentyfikowane na podstawie bibliografii zawartej w: Uniwersytet M. Kopernika 1945-1955, pod red. R. Galona, Warszawa 1957, s. 169; litera „c" - pozycje figurujące w sprawozdaniach i wykazach Skryptu (Arch. Państwowe w Toruniu: Akademicka Księgarnia Spółdzielcza Skrypt 3: Bilanse oraz 2: Ksiega protokolów Walnych Zgromadzeń)

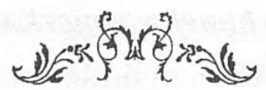

Przypisy:

'W. Jastrzębski, J. Sziling, Z dzialalności organizacji studenckich na UMK w Toruniu w latach 1945-1948, [w:] Materialy ogólnopolskiego seminarium poświęconego historii ruchu mlodzieżowego w woj. pomorskim (bydgoskim) w latach 1945-48, Torun 1963, s. 48. Zob. też: R. Becker, Historia organizacji mlodzieżowych na UMK w latach 1945-1948, Biuletyn Informacyjny. Uniwersytet M. Kopernika, 1976 [styczeń], s. 24 .

${ }^{2}$ H. Galus, Ruch studencki w Toruniu w latach 1945-1960, Toruń 1961, s. 53, 58; Tenże: Od „Cukierni Akademickiej" do grup twórczych. (Studencki nuch kulturalny w Toruniu w latach 1945-1965), Rocznik kulturalny Kujaw i Pomorza T. 2 : 1965, s. 145.

${ }^{3}$ Serdecznie dziękuje prof. Marianowi Kryszewskiemu oraz jego małżonce Julii Kryszewskiej za życzliwe zainteresowanie i pomoc w poszukiwaniu osób związanych z Akademicką Księgarnią Spółdzielczą. Dziękuje także prof. Adeli Styczyńskiej za udzielone informacje.

${ }^{4}$ H. Galus, Od „Cukierni..., s. 143-144, Tenże: Ruch studencki.., s. 51. Zob. też: W. Jastrzębski, J. Sziling, Z dzialalności..., s. 44.

${ }^{5}$ H. Galus, Ruch studencki..., s. 51-53.

"Arch. UMK Torun: DzN 14/10 Bratnia Pomoc, s. 1: Sprawozdanie z działalności ogólnej Bratniej Pomocy Studentów UMK w Toruniu za okres 1.10.1945 do 31.12.1946 roku.

${ }^{7} \mathrm{H}$. Galus podaje także przedstawicieli ZMW „Wici”, ZMA „Jedność”". Nie wymienia natomiast przedstawicieli OM TUR. Zob. H. Galus, Ruch studencki.., s. 52.

${ }^{8}$ Arch. UMK Toruń: DzN 14/10, k. 291.

${ }^{9}$ H. Galus, Ruch studencki.., s. 52 - 53.

${ }_{10}$ Pod koniec roku akademickiego 1945-1946 Bratnia Pomoc zorganizowała studenckie zakłady usługowe: szewski, krawiecki, fryzjerski, stolarski, pralnię, które świadczyły swoje usługi studentom (z. 50\% zniżka) oraz mieszkańcom miasta. Zob.: H. Galus, Ruch studencki..., s. 53 .

"Tamże, s. 54.

${ }^{12}$ Zob. L. Goliński, Na marginesie nowej studenckiej powieści, Trybuna Ludu 1955 nr 90, s. 4; A. Biernacki, Prawda mimo woli, Twórczość 1955 nr 9, s. 164 - 166; Z.P., Dziś i Jutro 1955 nr 20, s. 5; B. Dudziński, Dwukrotna inauguracja, Trybuna Wolności 1955 nr 25, s. 7.

${ }^{13}$ Tamże, s. 12.

${ }^{14}$ Tamże, s. 18. 
${ }^{15}$ H. Galus, Od , Cukierni..., s. 144.

${ }^{16}$ Archiwum Państwowe w Toruniu (dalej cyt.: AP Toruń): Akademicka Księgamia Spółdzielcza „Skrypt” (dalej cyt.: AKS „Skrypt”) 1, s. 23: Protokół nr 1 Zgromadzenia Założycielskiego Spółdzielni. W relacji Barbary Zdrójkowskiej-Wojciechowskiej Spółủzielnia została założona w porozumieniu, a nawet na prośbę ówczesnego dziekana Wydziału Prawnego (Rozmowa telefoniczna z B. Wojciechowską z dnia 5.03.1999). W tym okresie funkcję tą pełnil prof. zwyczajny dr Michał Wyszyński (Uniwersvtet Mikolaja Kopernika 1945-55, pod red. R. Galona, Warszawa 1957, s. 249). Niestety nie udało mi się potwierdzić tej informacji.

${ }^{17} \mathrm{~W}$ sprawozdaniu z zebrania założycielskiego zamieszczonym w loklalnej prasie jest mowa o 55 uczestnikach tego spotkania. Zob. Kronika tonunska: Z zycia akademickiego, Robotnik Pomorski 1945 nr I58, s.4.

is B. Zdrójkowska po ukończeniu studiów przeniosła się do Bydgoszczy, gdzie otrzymała stanowisko asesora sądowego (Zob. Arch. UMK Tonı́n: Zdrójkowski Zbigniew K $53 \mathrm{~N} / 79$, k. 188).

${ }^{19}$ Arch. UMK Toruń: Kryszewski Marian K-8/204, k. 11: Życiorys. Obecnie prof. M. Kryszewski jest członkiem rzeczywistyın PAN, zwiazanym z Centrum Badań Molekularnych i Makromolekularnych PAN w Łodzi (Informator nauki polskiej, T. 4: Ludzie nauki, Warszawa 1996, s. 338).

${ }^{20}$ Barbara Zdrójkowska i Zbigniew Zdrójkowski byli rodzenistwem. Z. Zdrójkowski ukończył Wydział Prawa Uniwersytetu Warszawskiego. W okresie organizowania Skryptu pracował jako referent do spraw prawnych i podatkowych Okręgu Pomorskicgo Związku Rewizyjnego Spółdzielni R.P. w Toruniu. Wkrótce potem (w grudniu 1945) został asystentem przy Katedrze Prawa Skarbowego Uniwersytetı M. Kopemika (Zob.: Arch. UMK Toruń: Zdrójkowski Zbigniew K 53 N/79, k. 206). W związku z likwidacja Wydziału Prawnego na UMK, w latach 1952-66 związał się z Uniwersytetem Warszawskim. Od 1958 ponownie był zatrudniony na UMK (początkowo jako 2-gi etat) w charakterze prodziekana organizowanego wówczas Wydziału Prawnego. W 1971 otrzymał tytuł prof. nadzwyczajnego. Pozostał już w Toruniu pracując jako kierownik Zakładu Powszechnej Ilistorii Państwa i Prawa, później dyrektor Instytutu Historyczno-Prawnego. Zmarł 27 lutego 1995 roku w Toruniu (Pracownicy nauki i dydaktyki Uniwersytetu M. Kopernika 1945-1994. Materialy do biografii, pod red. S. Kalembki, Torun 1995, s. 784-785).

${ }^{21}$ AP Toruń: AKS ,Skrypt” 1, s. 24: Protokół nr 1 Zgromadzenia Założycielskiego

${ }^{22}$ Tamże, s. 25-26: Protokół nr 1 posiedzenia Rady Nadzorczej

${ }^{23} \mathrm{~W}$ tym okresie T. Cieślak pracował w Zw. Samopomocy Chłopskiej w Toruniu. Jednocześnie przygotowywał pod kierunkiem prof. dr hab. K. Koranyi'ego prace doktorską którą obronił już w 1947 roku. Wkrótce potem, w 1948 roku, został sekretarzem i dyrektorem administracyjnym uniwersytetu. Od 1951 związał się z Uniwersytetem Eódzkim, gdzie otrzymał tytuł zastępcy profesora. W późniejszym okresie, od 1954 był profesorem i rektorem Szkoły Głównej Służby Zagranicznej w Warszawie. W 1. 1974-85 był kierownikiem Zakładu Historii Stosunków Polsko-Radzieckich w Instytucie Historii PAN. Zmarł 18.XI.1985 w Warszawie (Pracownicy nauki..., s. 141-142). T. Cieślak to przypuszczalnie Stolarczyk z. Inauguracji Z. Wróbla.

${ }^{24}$ Tamże, s. 29: Zgłoszenie do Sądu Okręgowego w Toruniu

${ }^{25}$ Tamże, s. 27: Deklaracja przystapienia do Związku Rewizyjnego Spółdzielni R.P.

${ }^{26}$ L. Reinschmidt, Spóldzielczość w Polsce, Warszawa 1946, s. 10-11. 
${ }^{27}$ Archiwum Akt Nowych w Warszawie (dalej cyt.: AAN Warszawa): Centrala Spółdzielni Wydawniczych i Księgarskich w Warszawie (dalej cyt.: CSWiK) 166: „Skrypt”, s. 1-2.

${ }^{28}$ Spóldzielnie uczniowskie były ściśle powiązane ze szkołami, pozostawały pod opieką nauczycieli i współdziałały z nauczycielskimi spółdzielniami wydawniczymi. (Zob.: Z. Chyra-Rolicz, Pod spótdzielczym sztandarem. Z dziejów spóldzielczości polskiej do 1982 roku, Warszawa 1985, s. 127). Przypuszczalnie z tego względu rektor UMK nie podjął się tego zadania nie chcąc się angażować w działalność Skryptu w trudnym okresie organizowania uczelni.

${ }^{29}$ AP Torun: Związek Rewizyjny Spółdzielni R.P. w Toruniu 1: Akademicka Księgarnia Spółdzielcza „Skrypt” (dalej cyt.: ZRS R.P. 1: AKS „Skrypt”), s. 1: Oświadczenie o celowość.

${ }^{30}$ AP Toruń: AKS ,Skrypt” 1, s. 5-20: Statut Akademickiej Księgami Spółdzielczej „Skrypt".

${ }^{31}$ AP Torun: AKS „Skrypt” 1, s. 109-111: Protokół z Walnego Zebrania Akademickiej Księgarni Spóldzielczej z 17.III.1948.

${ }^{32}$ AP Toruń: Z RS R.P. 1 : AKS ,Skrypt”, s. 11.

${ }^{33}$ Arch. UMK Torun: DN-1/21,k. 1.

${ }^{34}$ AP Torun: AKS ,Skrypt” 3: Bilanse, s. 85.

${ }^{35}$ AAN Warszawa: CSWiK, 166: Skrypt, s. 93.

${ }^{36}$ Alma Mater Thorunensis 1946 nr 1-2 s. 2; nr 3 s. 2 ; nr 4 s. 15; nr 5/6 s. 28.

${ }^{37}$ AP Toruń: AKS „Skrypt” 2: Księga protokołów Walnych Zgromadzeń, s. 9-14.

${ }^{38}$ Koło Prawników działało w latach 1946-1953, bylo jednym z 14 istniejących w tym okresie na toruńskiej uczelni. W swoich szeregach skupiało studentów najliczniejszego wydziału. W początkowym okresie praca Koła Prawników, jak i pozostałych, nie miała ściśle naukowego charakteru. Oprócz przedsięwzięć naukowych, zajmowano się organizowaniem życia kulturalno-towarzyskiego, a nawet sprawami socjalno-bytowymi. Zob.: H. Galus, Ruch studencki..., s. 55, 86.

${ }^{39}$ Po uzyskaniu dyplomu magistra w 1947 roku pracował jako starszy asystent w Katedrze Skarbowości i Prawa Skarbowego. W 1964 otrzymał tytuł profesora nadzwyczajnego, w późniejszym okresie związał się z Uniwersytetem Gdańskim. Zob.: Pracownicy..., s. 302.

${ }^{40}$ AP Toruń: AKS ,Skrypt” 3: Bilanse, s. 47. Powyższe powody były tylko pretekstem, w rzeczywistości Spółdzielnia Skrypt zwolniona była z tego typu obowiązków (Zob. AP Toruń: AKS „Skrypt” 2: Księga protokołów Walnych Zgromadzeń, s. 12.). Niestety rzeczywistych powodów swojej rezygnacji z Zarządu Barbara Zdrójkowska -Wojciechowska nie pamięta (rozm. telefoniczna z 25.03.1999).

${ }^{41}$ AP Toruń: AKS „Skrypt” 2: Księga protokołów Walnych Zgromadzeń, s. 20.

${ }^{42}$ Tamże, s. 22.

${ }^{43}$ Tamże, s. 25-26.

${ }^{44}$ Tamże, s. 32.

${ }^{45}$ AP Toruń: AKS ,Skrypt” 1, s. 117.

${ }^{46}$ Arch. UMK Torun: DN-1/21, k. 9-10.

${ }^{47}$ AP Toruń: AKS ,Skrypt” 1, s. 46.

${ }^{48}$ Tamże, s. 75.

${ }^{49}$ W roku akademickim 1945/46 przyjęto na I rok studiów UMK 1264 studentów, 
z czego $47 \%$ to studenci Wydziału Prawa. Zob.: H. Moraczewska, Nabór na studia dzienne w Uniwersytecie M. Kopernika w okresie 1945-1976, Rocznik kulturalny Kujaw i Pomorza T. 9: 1975-76, s. 52.

${ }^{50}$ AP Torun: AKS „Skrypt” 2: Księga protokołów Walnych Zgromadzeń, s. 35.

${ }^{51}$ AP Toruń: AKS ,Skrypt" 1, s. 161.

${ }^{52}$ Tamże, s. 119.

${ }^{53}$ AAN Warszawa: CSWiK, 166: Skrypt, s. 112.

${ }^{54}$ Tamże, s. 18-20: Sprawozdanie za 1.01-1.06.1946.

${ }^{55} \mathrm{~W}$ relacji B. Zdrójkowskiej-Wojciechowskiej skrypty przynajmniej częściowo rozdawano bezpłatnie (rozm. telefoniczna z 25.03.1999).

${ }^{56}$ Wyliczenia własne na podstawie danych ze sprawozdania za I półrocze 1946 roku. Średnia objętość skryptów dla Wydz. Prawa wynosiła w tym okresie 220 s., Wydz. MatematycznoPrzyrodniczego - 120 s., Wydz. Humanistycznego - 60 s. Tylko podręczniki przeznaczone dla prawników przekraczały nakład 100 egz.

${ }^{57}$ AP Torun: AKS ,Skrypt" 3: Bilanse, s. 31.

${ }^{58}$ W 1947 roku Spółdzielnia wykazała w specyfikacji pozycji „Straty na towarach” 14 różnych skryptów w ilości od 200 (Teksty flozoficzne) do 1 (Anatomia cz. I) egzemplarza. (Zob.: AAN Warszawa: CSWiK, 166 „Skrypt”, s. 91.).

${ }^{59}$ AP Toruń: AKS „Skrypt” 2: Księga protokołów Walnych Zgromadzeń, s. 41 oraz 3: Bilanse, s. 141.

ro Sąd Okręgowy w Toruniu wpisał Skrypt 9 stycznia 1946 roku do Rejestru Spółdzielni pod nr 58 (AP Toruń: AKS ,Skrypt” 1, s. 31-32).

${ }^{61}$ AP Toruń: AKS „Skrypt” 1, s. I15: Sprawozdanie Zarządu za rok 1946.

"2. AAN Warszawa: CSWiK 166: „Skrypt”, s. 20.

${ }^{63}$ Tamże, s. 100. W tym okresie w Szczecinie funkcjonowała Akademia Lekarska powołana dekretem z 20 marca 1948 oraz szkoła inżynierska (Zob.: Historia nauki polskiej, pod red. B. Suchodolskiego, T. 5: 1918-1951, cz. I, Wrocław-Warszawa-Kraków 1992, s. 429).

${ }^{64}$ Przynajmniej w przypadku pierwszych skryptów studenci dostali gotowe maszynopisy od profesorów (rozm. telefoniczna z B. Zdrójkowską-Wojciechowską z 25.03.1999).

"s AP Toruń: ZRS R.P. 1: AKS „Skrypt”, s. 21: Protokół z lustracji z dnia 12-18 listopada 1947; Kronika toruńska: Z życia akademickiego, Robotnik Pomorski $1945 \mathrm{nr} 60$, s. 4.

"AP Torun: AKS „Skrypt” 3: Bilanse, s. 139.

${ }^{67} \mathrm{~J}$. Gadomski, Przewodnik po wystawie przemysh poligraficznego w Tonuniu, Toruń 1947, s. 13.

${ }^{68}$ AP Torun: AKS „Skrypt” 2: Księga protokołów Walnych Zgromadzeń, s. 6-8.

(9) J. Mikulski, Katedra Anatomii Czlowieka i Higieny Szkolnej, [w:] Uniwersytet Mikolaja Kopernika 1945-55..., s. 207.

${ }^{70}$ J. Hurynowicz, Katedra Newrofizjologii i Fizjologii Porównawczej, lbidem, s. 199;

J. Prüffer, Katedra Zoologii Systematycznej, lbidem, s. 193.

7 J. Prüffer, Wydzial Matematyczno-Przyrodniczy, Ibidem, s. 109.

${ }^{72}$ B. Nadolski, Wydzial Humanistyczny, lbidem, s. 38-39.

${ }^{73}$ AP Toruń: AKS „Skrypt” 1, s. 117.

${ }^{74} \mathrm{~W} 1993$ roku ukazało się wznowienie tej pracy przygotowane i opracowane przez Teresę Borawską. Zob.: T. Borawska, K. Górski, Umyslowość Średniowiecza, Warszawa 1993. 
${ }^{75}$ AP Toruń: ZRS R.P. 1: AKS „Skrypt”, s. 21.

${ }^{76}$ Zob. np.: T. Szczurkiewicz, Historia socjologii. Zeszyt 1, [b. m. wyd.] [b. r. wyd.].

${ }_{77}$ R. Krupa, S. Stanuch, ABC Komputerowo drukarsko wydawnicze, Kraków 1994, s. 314.

${ }^{78}$ Arch. UMK Toruń: DN-1/21, k. 4

${ }^{79} Z$ zycia akademickiego, Alma Mater Thorunensis $1946 \mathrm{nr} 1-2, \mathrm{~s} .2$.

${ }^{80}$ Arch. UMK Torun: DzN 14/10, k. 79.

${ }^{81}$ Tamże, k. 97.

${ }^{R 2}$ S. Pazyra, Z dziejów ksiazki polskiej u' czasie drugiej wojny światowej, Warszawa 1970.

${ }^{83}$ Arch. UMK Torun: DN-1/21, k. 2.

${ }^{84}$ Arch. UMK Toruń: DzN 14/10, k. 47.

${ }^{85}$ Tamże: k. 46.

${ }^{86}$ Tamże: k. 50.

${ }^{87}$ Tamże: k. 297, 298.

${ }^{8}$ AP Toruń: AKS ,Skrypt” 3: Bilanse, s. 33.

${ }^{89}$ Tamże, s. 7.

4n Tamże, s. 113.

${ }^{91}$ AP Toruń: ZRS R.P. 1: AKS „Skrypt”, s. 21, 23: Protokół z lustracji z dnia 12-18 listopada 1947.

${ }^{92}$ Arch. UMK Toruń: DN-1/21, s. 8.

${ }^{43}$ AP Toruń: AKS ,Skrypt” 1, s. 45: Protokół z zebrania Rady Nadzorczej z 19.12.1956.

${ }^{14}$ Zakład Dokumentacji Księgoznawczej Biblioteki Narodowej w Warszawie: Arch. Stowarzyszenia Księgarzy Polskich, Spuścizna F. Pieczątkowskiego: ZKP 1946-48.

${ }^{45}$ Prof. Jerzy Serczyk, ówczesny student Wydziału Humanistycznego nabył dwa czy trzy numery tego pisma w kiosku Skryptu. Rozmowa telefoniczna z prof. J. Serczykiem z dnia 14 października 1998.

" AP Toruń: AKS ,Skrypt” 1, s. 117: Sprawozdanie Zarządu za rok 1947.

${ }^{97}$ AP Toruń: AKS ,.Skrypt" 3: Bilanse, s. 39.

98 Tamże, s. 155. Zachowałam kolejność w jakiej wydawnictwa te były wymienione w wykazie, uzupełniając tylko - w przypadku ustalenia - o miejsce i rok wydania.

"99 AAN Warszawa: CSWiK, 166 ,Skrypt”, s. 128.

${ }^{100}$ Arch. UMK Toruń: DN-1/21, k. 1.

${ }^{101}$ AP Toluń: ZRS R.P. I: AKS „Skrypt”, s. 5: Sprawozdanie z wizytacji z dnia 4 kwietnia 1946. W początkowym okresie istnienia Spóldzielni, jej biuro mieściło się w pokoju nr 227 na II piętrze Domu Akademickiego. Zob. Kronika tonıńska: Z życia akademickiego, Robotnik Pomorski 1945 nr 160 s. 4; nr 161 s. 3.

102 Tamże, s. 19: Protokół z lustracji z dnia 12-18 listopada 1947.

103 Tamże, s. 117: Sprawozdanie Zarządu za rok 1947.

${ }^{104}$ AP Toruń: AKS ,Skrypt” 3: Bilanse, s. 48.

${ }^{105}$ List pani prof. dr hab. Adeli Styczyńskiej z dnia 29.08.1998.

${ }^{106}$ Zżvia akademickiego, Alma Mater Thorunensis 1946 nr 1-2, s. 2; AP Toruń: ZRS R.P.

1: AKS „Skrypt”, s. 5: Sprawozdanie z wizytacji z dnia 4 kwietnia 1946.

${ }^{107}$ Niestety nie udało się ustalić imienia tej studentki.

${ }^{108}$ AP Toruń: AKS ,Skrypt” 1, s. 117.

${ }^{109}$ AP Toruń: ZRS R.P. 1: AKS „Skrypt”, s. 5. 
${ }^{130}$ AP Toruń; AKS „Skrypt” 3: Bilanse, s. 45: Sprawozdanie za rok 1947.

"'I AP Toruń: ZRS R.P. 1: AKS ,.Skrypt”, s. 21 : Protokół z lustracji z dnia 12-18 listopada 1947.

112 A. Tonú: AKS „Skrypt” 1, s. 73.

113 Tamże, s. 121: Umowa o pracę.

114 Tamże, s. 73, 123: Umowa o pracę.

115 Tamże, s. 59: Umowa o pracę.

${ }^{116}$ AP Toruń: ZRS R.P. 1: AKS „Skrypt”, s. 19: Protokół z lustracji z dnia 12-18 listopada 1947.

${ }^{117}$ AP Toruń: AKS „Skrypt” 1, s. 71.

118 Tamże, s. 143: Umowa o pracę.

114 Tamże, s. 171.

120 J. Bełkot, Uniwersytet Mikolaja Kopernika w Toruniu w latach 1945-85, Torun 1986, s. 139.

${ }^{121}$ Pracownicy nauki i dydaktyki..., s. 134-135, 141-142, 378-379.

122 S. A. Kondek, Wladza i wydawcy. Polityczne uwartunkowania produkcji ksiażek w Polsce w latach 1944-1949, Warszawa 1993, s. 120.

${ }^{123}$ Centrale zapewniały poszczególnymn typom spółdzielni pomoc gospodarczą i instrukcyjno-rewizyjn̨, natomiast Centralny Związek Spółdzielczy spełniał rolę naczelnej organizacji ruchu spółdzielczego. W następnych latach przyszły kolejne zmiany, w 1949 - ograniczono samorząd spółdzielczy, w 1950 - zlikwidowano 4 z 8 działających central, wśród nich Centralę Spółdzielni Wydawniczych i Księgarskich. Zob. Z. Switalski, Spóldzielczość w Polsce Ludowej 1944-1968. Wybór dokumentów, Warszawa 1970, s. 480-481.

${ }^{124}$ S. A. Kondek, op. cit., s. 122.

${ }^{125}$ AAN Warszawa: CSWiK, 166 ,Skrypt”, s. 129-130.

${ }^{126}$ AP Torun: AKS ,Skrypt” 1, s. 153.

127 Tamże, s. 127-128.

${ }^{128}$ Tamże, s. 155.

${ }^{129}$ AAN Warszawa: CSWiK, 166 „Skrypt”, s. 131.

${ }^{130}$ AP Toruń: AKS ,Skrypt” 1, s. 153-155. 